\title{
The impact of intrinsic satisfaction factors on affective, normative, and continuance commitment of accounting professionals in Tunisia
}

\author{
Lassaad Abdelmoula ${ }^{\text {a1 }}$ \\ ${ }^{a}$ Faculty of Economics and Management of Sfax, Tunisia
}

\begin{abstract}
Research question: The objective of the present research work was to examine the effect of the intrinsic determinants of satisfaction on the accounting professionals' organizational commitment (OC) in Tunisia.

Motivation: Only few works have focused on the accounting profession. As a result, our research aimed to bridge this gap in the literature and focus on accounting professionals.

Idea: Our study aimed to examine the effect of intrinsic determinants of satisfaction on accounting professionals' affective, normative, and continuance commitments in Tunisia.

Data: As part of the research, we chose to use two administration methods: face-to-face and internet surveys. The methodology was applied to 180 accounting professionals. Out of 204 accounting professionals, we received 192 responses. A total of 12 questionnaires were rejected due to missing data. Thus, 180 collected questionnaires were considered.

Tools: To the ends of our research, we relied on the principal component analysis to reduce the items to a limited number of components. The three dimensions of OC, i.e., affective, normative, and continuance, were assessed concurrently to present the existing interactions for each equation. This choice is justified by the presence of a high endogeneity risk between the intrinsic factors and each dimension. To surmount this problem, the simultaneous equation model was estimated by means of the seemingly unrelated regression (SUR) approach.
\end{abstract}

Findings: Our findings prove that intrinsic determinants of satisfaction, namely achievement, advancement, work itself, recognition, and growth, have a positive and significant effect on the three dimensions of OC.

1 Corresponding author: Lassaad Abdelmoula, Department of Accounting, Faculty of Economics and Management of Sfax, Tunisia; tel. (+216)44571871, email address:lassaad.abd86@ gmail.com 
Contribution: Our findings contribute to a better understanding of the effect of intrinsic determinants of satisfaction on the three dimensions of $\mathrm{OC}$ of accounting professionals.

Keywords: Accounting professionals, intrinsic satisfaction factors, organizational commitment, Tunisia.

\section{JEL Codes: M41}

\section{Introduction}

Nowadays, the technical-economic parameters are no longer sufficient to account for the functioning of firms; thus, there is a tendency to integrate behavioral sciences in the study of work behavior. Hence, the interest in identifying the professional attitudes and behaviors of professional accountants at work. Generally, competence, professionalism, and commitment to the field of work are the main determinants of success in a profession. Commitment shows the extent of involvement in the firm. It can, therefore, lead to a sense of belonging to the firm. Employee commitment to the firm is crucial as it can be an indicator of job turnover intention.

Previous studies dealing with the impact of satisfaction at work on organizational commitment (OC) dealt mainly with jobs like teachers (Malik et al., 2010), nurses (Top \& Gider, 2013), doctors (Tosun \& Ulusoy, 2017), and employees in general (Gomeshu Goa \& Fanta, 2018). Nonetheless, to date, little research has been conducted on accounting professionals. Therefore, we aimed to bridge this gap by studying the effect of satisfaction at work on accounting professionals' OC in Tunisia.

Herzberg et al. (1959), in their theory of job satisfaction, differentiated intrinsic and extrinsic determinants of satisfaction at work. Our work focused on the effect of the former on the accounting professionals' OC, which consists of three dimensions: affective, normative, and continuance. Affective commitment refers to the psychological attachment to the firm. For example, Meyer \& Allen (1993) believe that affective commitment is a positive feeling for the firm and a sense of pride for belonging to it. Normative commitment can be defined as the obligation to stay in the firm. It affects the continuing contribution of the professional to the firm.

Continuance commitment represents the individual's understanding of the costs of quitting the firm (Meyer et al., 1993). Thus, quitting one's job seems difficult due to the unidentified 'opportunity cost' or the scarcity or absence of options. In short, those who have high continuance commitment stay in their works because they need them (Meyer \& Allen, 1993). To meet the objective of our research, we adopted a particular methodology that aimed at emphasizing the impact of the intrinsic 
satisfaction factors on affective, normative, and continuance commitment of accounting professionals in Tunisia. Out of 204 accounting professionals, 192 answers were received. The questionnaires with missing data (12) were eliminated. Hence, our final sample was composed of 180 accounting professionals.

The remainder of the paper is structured as follows: The accounting profession in Tunisia is described in Section 2. The review of the literature and the hypotheses development are outlined in Section 3. Section 4 highlights the research methodology. Section 5 presents the results and discussion. The academic and managerial implications, as well as the limitations of the work are presented in the last section.

\section{The accounting profession in Tunisia}

The accounting profession mainly includes accountants, chartered accountants, academics, teachers, and corporate and public accountants. All these professionals have contributions to the profession in their fields of expertise. This profession also guarantees the trustworthiness and transparency of financial and non-financial information and plays a central role in working with governments and their departments. Accounting professionals play a crucial role in identifying and implementing high-quality standards. Several authors (e.g., Westland, 2010; Dubar et al., 2011; Abdelmoula \& Boudabbous, 2020) believe that this profession is a collective representation of members who can congregate in an order to "protect themselves against the risks of liberalism and maintain social respectability" (Sarfatti, 1977). The collective spirit is materialized by sharing a code of ethics, standards, and values. Indeed, two professional corporations, namely the Order of Chartered Accountants in Tunisia, which was created in 1988, and the Company of Accountants in Tunisia, which was established in 2002, organize the accounting profession in Tunisia. These two organizations are governed respectively by law $\mathrm{n}^{\circ} 88-108$ of 18 August 1988 and law n ${ }^{\circ} 2002-16$ of 4 February 2002 for accountants.

Accounting professionals working in accounting companies in Tunisia can be classified into three types: chartered accountants, chartered accountant trainees, and accountants (Abdelmoula \& Boudabbous, 2020). First, an accountant is someone who has a bachelor's degree or a higher education qualification in accounting or an equivalent qualification accepted by the specialized equivalence committee of the Ministry of Higher Education. Second, a chartered accountant is a professional who organizes, validates, corrects, and evaluates the accounts of firms with which he has no employment contract. A chartered accountant can also audit companies and, thus, be approved to validate the fairness and truthfulness of the financial statements based on the Tunisian General Admitted Accounting Principles (GAAP) and also provide advisory services. Finally, a chartered accountant trainee is a person who has a bachelor's degree in accounting and who succeeds in the national accounting 
diploma exam. Upon passing this exam, he has to complete a work placement of three years under the control of the "Order of Chartered Accountants of Tunisia" (OCAT).

As for accountants, the number of accountants (natural persons) is 1266, the number of accountants (accounting firms) is 146, and that of accountant trainees is 615. For chartered accountant trainees, the number is 400 . Finally, for chartered accountants, the number of chartered accountants natural persons is 1122, while that of accounting firms is 453. The central roles of accounting professionals are: first, to advise companies on legal, tax, and social matters; second, to contribute to strengthening public finance; and finally, to contribute to proposing the necessary laws (financial laws, etc.).

\section{Literature review and hypotheses development}

An in-depth reading of the literature on the consequences of satisfaction at work shows that it is a topic of considerable interest for firms because of its effect on their affective, normative and continuance commitment. The technical-economic parameters are no longer sufficient to account for the functioning of firms. In this respect, the synergy between the different components of the organizational commitment and the satisfaction at work is a motivation that the company to integrate attitude and behavioral sciences in the study of work behavior. The association between satisfaction at work and $\mathrm{OC}$ is based on the social exchange theory (SET) that offers the theoretical background for our work (Blau, 1964). Prat dit Hauret (2006), Gunlu et al. (2010), and Gomeshu Goa \& Fanta (2018) studied the impacts of satisfaction at work on OC and found that the satisfaction at work has a slightly strong and statistically significant association with affective commitment and a positive and statistically significant relationship, though weak, with normative commitment. Nevertheless, it is negatively correlated with continuance commitment. In this context, the interaction between satisfaction at work and the dimensions of commitment is a policy in order to ensure firms legitimacy and to reduce the interest conflict. Several previous works (e.g., Aranya et al., 1982; Srivastava, 2013; Top \& Gider, 2013; Sejjaaka \& Kaawaase, 2014; Sreehari et al., 2014) studied the association between satisfaction and OC and showed that satisfaction at work has a positive and significant effect on OC.

Historically, the subject of satisfaction at work is extremely common in the international accounting debate as it is a key element in understanding a company's performace. Abdelmoula and Boudabbous (2020) concluded that extrinsic job satisfaction have a positive and significant effect on OC. Furthermore, Abdelmoula (2020) found that organizational commitment plays a mediating role in the relationship between job satisfaction and performance. 
Similarly, Thabane et al. (2017) studied the same relationship and showed that satisfaction at work has a strong association with affective commitment, a moderate relationship with normative commitment, but a weak relationship with continuance commitment. Gangai and Agrawal (2015) demonstrated that only continuance commitment and normative commitment are significantly associated with satisfaction at work.

Likewise, Tat et al. (2012) and Setiawan and Ghozali (2013) state that job design has a weak but significant association with affective commitment and that the other factors of satisfaction at work and OC are not significantly correlated. In the same vein, Susanto (2012), Shafazawana et al. (2016), and Tosun and Ulusoy (2017) proved that satisfaction at work affects OC dimensions.

The relationship between job satisfaction and organizational commitment of accounting professionals has also attracted much interest. Indeed, job satisfaction is considered an early indicator of OC in auditor turnover (Gregson, 1992). The higher auditor's motivation, the higher the impact of OC on satisfaction at work. Hence our first hypothesis:

H1: Satisfaction at work affects accounting professionals' affective, normative and continuance commitment positively and significantly.

Herzberg et al. (1959) supposed that satisfaction and dissatisfaction are two distinct and occasionally even unconnected phenomena. Intrinsic determinants, called "motivators", are inherent in the nature and experience to do the work. They include achievement, advancement or promotion, recognition, the work itself, growth, and responsibility. Nevertheless, extrinsic determinants, called hygiene factors, embrace the company policy, work security, relationship with the supervisor, salary, relationship with peers, personal life, status, and working conditions). Hence the present research was based on the work of Hong and Waheed (2011) that used six intrinsic factors of satisfaction, namely achievement, advancement or promotion, recognition, the work itself, and growth.

The present work focused on the intrinsic determinants of Herzberg; hence the subhypotheses are as follows:

H1.1: Intrinsic satisfaction affects accounting professionals' affective commitment positively and significantly.

H1.2: Intrinsic satisfaction affects accounting professionals' normative commitment positively and significantly.

H1.3: Intrinsic satisfaction affects accounting professionals' continuance commitment positively and significantly. 


\section{Our research model is depicted in figure 1.}

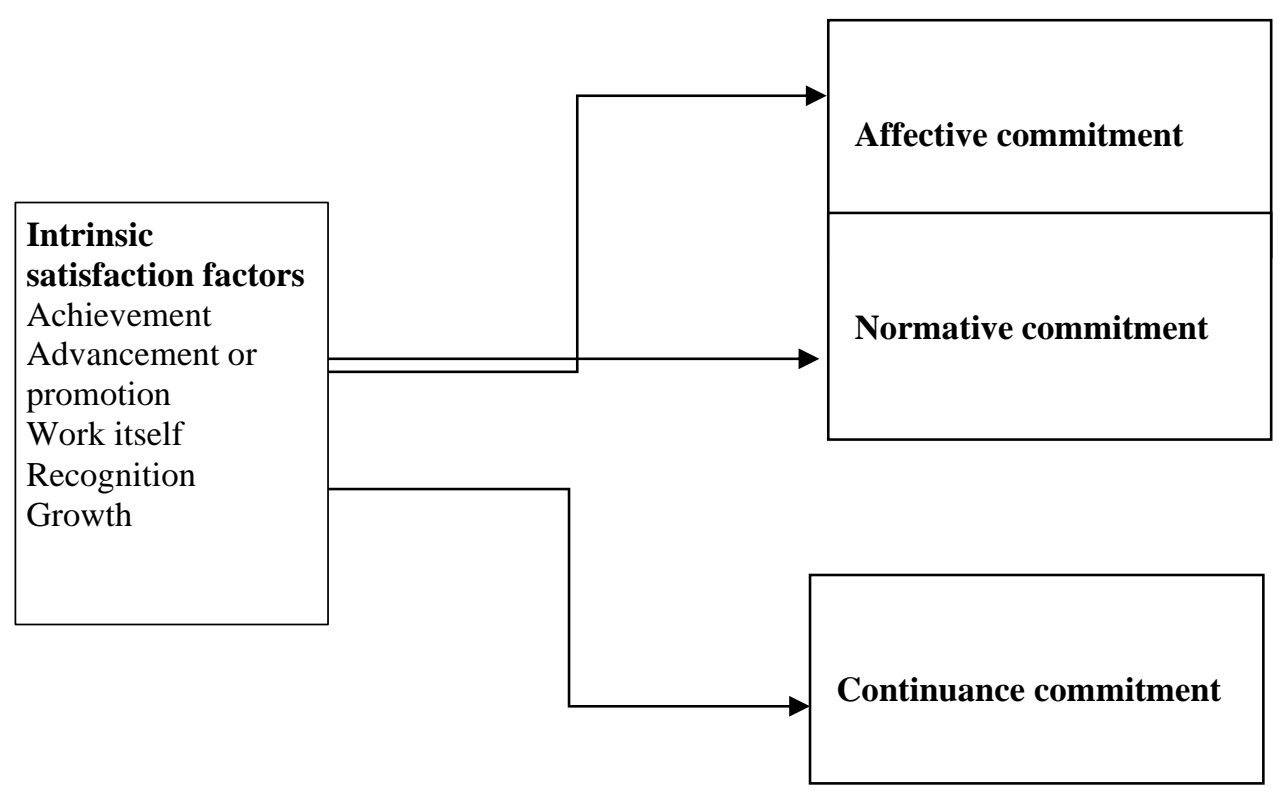

Figure 1. Research model

\section{Research methodology}

\subsection{Method of data collection}

Two administration methods: face-to-face and internet surveys were chosen in this work (Evrard, 2009). The surveys were carried out in Sfax and Tunis during March, April, and May 2020. The face-to-face survey allowed us to be present during the meeting with the interviewees. We made sure that the questionnaires were duly completed to minimize the rate of incomplete responses. We clarified orally the study's objective and some questions without affecting the responses given by the interviewees. We administered the questionnaire through our network of professional connections. We also opted for administering our questionnaire via the internet due to the geographic dispersion of respondents. We used the Google Docs website to host our online questionnaire. To this end, we built our questionnaire and then published it on the website server. Out of 204 accounting professionals, we received 192 responses. A total of 12 questionnaires were rejected due to missing data. As a result, our final sample consisted of 180 accounting professionals.

Some of these data also form the empirical basis of Abdelmoula (2020). However, instead of focusing on the "extrinsic factors of job satisfaction, we examined the 
The impact of intrinsic satisfaction factors on affective, normative, and continuance commitment of accounting professionals in Tunisia

impact of the intrinsic satisfaction factors on affective, normative, and continuance commitment of accounting professionals in Tunisia (see Table 1 for a detailed distinction between the two studies).

Table 1. Data positioning

\begin{tabular}{|c|c|c|}
\hline & Abdelmoula (2020) & Current Study \\
\hline $\begin{array}{l}\text { Research } \\
\text { objective }\end{array}$ & $\begin{array}{l}\text { Studying the impact of } \\
\text { extrinsic job satisfaction } \\
\text { factors on the organizational } \\
\text { commitment of accounting } \\
\text { professionals in Tunisia }\end{array}$ & $\begin{array}{l}\text { Studying The impact of } \\
\text { intrinsic satisfaction factors on } \\
\text { affective, } \\
\text { normative, and continuance } \\
\text { commitment of accounting } \\
\text { professionals in Tunisia }\end{array}$ \\
\hline Empirical focus & Quantitative methods & Quantitative methods \\
\hline $\begin{array}{l}\text { Empirical } \\
\text { material }\end{array}$ & $\begin{array}{l}\text { Data collection was } \\
\text { administered through a } \\
\text { questionnaire addressed to } \\
145 \text { professionals working } \\
\text { in accounting firms in } \\
\text { Tunisia. The final sample } \\
\text { consisted of } 140 \text { accounting } \\
\text { professionals. }\end{array}$ & $\begin{array}{l}\text { The methodology was applied to } \\
180 \text { accounting professionals. Out } \\
\text { of } 204 \text { accounting professionals, } \\
\text { we received } 192 \text { responses. A total } \\
\text { of } 12 \text { questionnaires were rejected } \\
\text { due to missing data. Thus, } 180 \\
\text { collected questionnaires were } \\
\text { considered. }\end{array}$ \\
\hline Analytical lens & $\begin{array}{l}\text { The Pearson correlation } \\
\text { analysis }\end{array}$ & $\begin{array}{l}\text { the seemingly unrelated } \\
\text { regression (SUR) } \\
\text { approach. }\end{array}$ \\
\hline Key finding & $\begin{array}{l}\text { The extrinsic satisfaction } \\
\text { factors, namely company } \\
\text { policy, the relationship } \\
\text { with peers, the relationship } \\
\text { with the supervisor and } \\
\text { working condition have } \\
\text { positive and significant } \\
\text { impacts on organizational } \\
\text { commitment, excepting } \\
\text { salary and work security } \\
\text { which have a positive but } \\
\text { non-significant effect. }\end{array}$ & $\begin{array}{l}\text { Our findings prove that the } \\
\text { intrinsic satisfaction factors, } \\
\text { namely achievement, } \\
\text { advancement, work itself, } \\
\text { recognition, and growth, have a } \\
\text { positive and significant effect on } \\
\text { accounting professionals' } \\
\text { affective, normative, and } \\
\text { continuance commitment }\end{array}$ \\
\hline
\end{tabular}

Vol. 20, No. 2 


\subsection{Measurement of the variables}

\subsubsection{Intrinsic satisfaction determinants}

To date various methods have been developed and introduced to measure the satisfaction at work. In recent studies (Herzerberg et al. 1959; Smith et al.,1969 ; Spector, 1985; Hong \& Waheed, 2011), satisfaction at work has been measured by intrinsic and extrinsic factors. In this context, this variable was mesured according to the procedure used by Hong and Waheed (2011) which suggests that that used six intrinsic factors of satisfaction, namely achievement, advancement or promotion, recognition, the work itself, and growth.

\subsubsection{Organizational commitment}

Different authors have measured organizational commitment in a variety of ways (Mowday et al., 1979; Allen \& Meyer,1990; Rebele et al., 1996; Meyer \& Allen ,1997; Luttman et al., 2003). In this study, we measured organizational commitment using 18 items, according to Meyer \& Allen (1997). We define all the variables in our model in Table 2:

Table2. Measurement of the variables

\begin{tabular}{|c|c|c|}
\hline Variables & Measurements & Authors \\
\hline $\begin{array}{l}\text { Intrinsic satisfaction } \\
\text { determinants }\end{array}$ & $\begin{array}{l}\text { Achievement ( } 3 \text { items) } \\
\text { Advancement /or promotion ( } 2 \\
\text { items) } \\
\text { Work itself ( } 3 \text { items) } \\
\text { Recognition ( } 3 \text { items) } \\
\text { Growth (3 items) }\end{array}$ & $\begin{array}{l}\text { Hong \& Waheed } \\
\text { (2011) }\end{array}$ \\
\hline Organizational commitment & $\begin{array}{l}\text { Affective commitment (6 } \\
\text { items) } \\
\text { Normative commitment ( } 6 \\
\text { items) } \\
\text { Continuance commitment ( } 6 \\
\text { items) }\end{array}$ & $\begin{array}{l}\text { Meyer \& Allen } \\
\text { (1997) }\end{array}$ \\
\hline
\end{tabular}

\subsection{Data analysis method}

To the ends of our research, we relied on the principal component analysis to reduce the items to a limited number of components. The three dimensions of OC were estimated simultaneously to introduce the existing interactions for each equation. The choice of the simultaneous equation model is justified by the presence of a high endogeneity risk between the intrinsic factors and each OC dimension. To surmount 
this problem, the SUR approach was used to estimate the simultaneous equation model.

\section{Results and discussion}

\subsection{Principal Component Analysis (PCA)}

\subsubsection{The intrinsic factors of satisfaction at work}

Our sample included 180 accounting professionals. According to Saporta (2006), choosing the intrinsic factors of satisfaction at work for principal component analysis (PCA) is the most important step. We selected 14 items to determine the intrinsic factors of satisfaction at work. The matrix algorithm gives a histogram of eigenvalues representing the part of the total information each factor or main component contains. The different axes are independent of each other and intersect at the center of a cloud of points, matching the 180 professional accountants scattered in a space with the number of dimensions equal to the number of intrinsic determinants (14 items).

The first two PCA axes, related to the first and second eigenvalues, represent $53.6 \%$ of all the information. The third, fourth, and fifth axes represent 10.5, 8.6, and 7.4\%, respectively, i.e., $80.1 \%$ of the variance. Thus, these five axes are enough for the analysis (Table 3). The projection after varimax rotation of the 14 items on the mapping allows analyzing the bilateral relations existing between them. Moreover, the projection of the 14 items then allows us to determine their concrete meaning. On the circle of correlations between the first five principal components and the 14 items, we can see that the first factorial axis is "Recognition" that explains $29.9 \%$ of the total variance explained and the second is "Achievement", which explains $23.7 \%$ of the total variance explained.

The third factorial axis is "Growth", which explains $10.5 \%$ of the total variance explained. The fourth factor relating to "Work itself" explains $8.6 \%$ of the total variance explained. Finally, "Advancement" is the fifth factorial axis that represents $7.4 \%$ of the total variance explained (Appendix). Moreover, a Cronbach's alpha coefficient of 0.79904 gives us a satisfactory result as it exceeds the acceptance threshold set in our study. Thus, the 14 items retained are reliable. All the items measuring the intrinsic factors of satisfaction should be retained. It should be noted that the PCA allowed us to compress a considerable number of intrinsic determinants to identify the essential ones, i.e., five main types of distinct determinants (Recognition, Achievement, Work itself, Growth, and Advancement). 
Table 3. Eigenvalues $\lambda \kappa$ and percentage of variance explained by each factor axis.

\begin{tabular}{cccccc}
\hline $\begin{array}{c}\text { Factor } \\
\text { number }\end{array}$ & $\begin{array}{c}\text { Factor } \\
\text { loading }\end{array}$ & $\begin{array}{c}\text { Mean } \\
\text { responses }\end{array}$ & Eigenvalue & $\begin{array}{c}\text { Part of total } \\
\text { Variance } \\
\text { explained } \\
\text { (\%) }\end{array}$ & $\begin{array}{c}\text { Part of total } \\
\text { variance } \\
\text { explained } \\
\text { (cumulative\%) }\end{array}$ \\
\hline Recognition 1 & 0.6087 & 2.98 & 5.4859 & 29.9 & 29.9 \\
Recognition 2 & 0.7084 & 2.78 & & & \\
Recognition 3 & 0.6874 & 3.17 & & & \\
Achievement 1 & 0.7221 & 3.85 & 4.6096 & 23.7 & \\
Achievement 2 & 0.7145 & 4.08 & & & \\
Achievement 3 & 0.6921 & 3.14 & & & \\
Growth 1 & 0.8541 & 2.08 & 3.0359 & 10.5 & \\
Growth 2 & 0.6924 & 2.17 & & & \\
Growth 3 & 0.7081 & 2.89 & & & \\
\hline Advancement 2 & 0.7985 & 4.18 & & & \\
\hline Work Itself 1 & 0.8221 & 3.47 & 2.2710 & & \\
Work Itself 2 & 0.6395 & 3.98 & & & \\
Work Itself 3 & 0.7992 & 2.71 & & & \\
Advancement 1 & 0.7114 & 4.17 & & & \\
Ad & & & & \\
\end{tabular}

The PCA plot below represents the decrease in eigenvalues showing the associated factor axes deviation. The projection of the 14 items after a normalized varimax rotation extracts five intrinsic factors of satisfaction (figure 2).

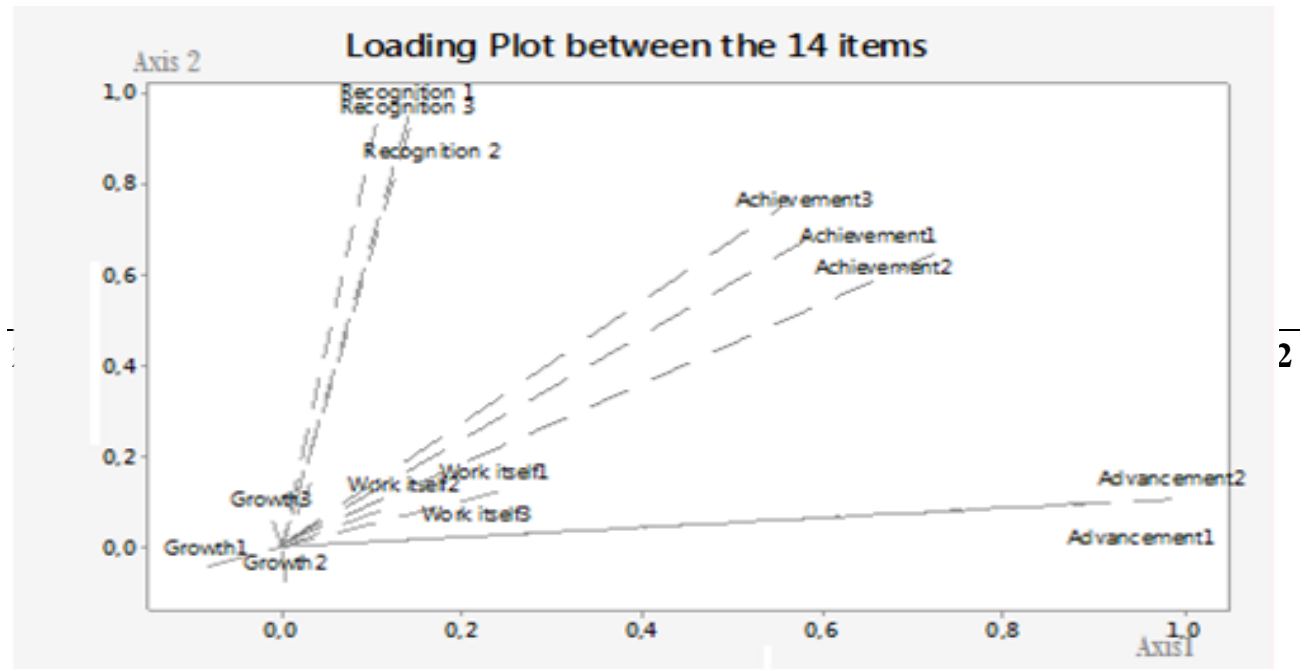


Figure 2. PCA of intrinsic satisfaction factors

\subsubsection{Organizational commitment factors (Saporta, 2006)}

The total variance explained by the three axes is of the order of $79.2 \%$, and they have eigenvalues greater than 1 (Table 4); hence, they are retained. This percentage shows that the eigenvalues of the retained axes represent a good proportion of the analysis because the sum of variance explained by each of the axes represents an important part of the total inertia. Indeed, each of these 18 items has at least one factor score of the order of 0.6214. Moreover, a Cronbach's alpha coefficient of 0.8098 gives us a satisfactory result since it exceeds the acceptance threshold set in our study, thus reflecting the reliability of the three retained dimensions.

The PCA plot below shows that the three factorial axes correspond respectively to "Affective commitment", "Normative commitment" and "Continuance commitment" (Appendix).

Table 4. Eigenvalues $\lambda \kappa$ and percentage of variance explained by each factorial axis.

\begin{tabular}{|c|c|c|c|c|c|}
\hline $\begin{array}{l}\text { Factor } \\
\text { number }\end{array}$ & $\begin{array}{l}\text { Factor } \\
\text { loading }\end{array}$ & $\begin{array}{c}\text { Mean } \\
\text { responses }\end{array}$ & Eigenvalue & $\begin{array}{l}\text { Part of total } \\
\text { variance } \\
\text { explained } \\
(\%)\end{array}$ & $\begin{array}{c}\text { Part of total } \\
\text { variance explained } \\
\text { (cumulative\%) }\end{array}$ \\
\hline $\begin{array}{c}\text { Affective } \\
\text { commitment } 1\end{array}$ & 0.7481 & 4.12 & 5.5528 & 29.5 & 29.5 \\
\hline $\begin{array}{c}\text { Affective } \\
\text { commitment } 2\end{array}$ & 0.6214 & 3.17 & & & \\
\hline $\begin{array}{c}\text { Affective } \\
\text { commitment } 3\end{array}$ & 0.8214 & 2.99 & & & \\
\hline $\begin{array}{c}\text { Affective } \\
\text { commitment } 4\end{array}$ & 0.7221 & 3.85 & & & \\
\hline $\begin{array}{c}\text { Affective } \\
\text { commitment } 5\end{array}$ & 0.7145 & 4.08 & & & \\
\hline $\begin{array}{c}\text { Affective } \\
\text { commitment } 6\end{array}$ & 0.6921 & 3.14 & & & \\
\hline
\end{tabular}




\begin{tabular}{|c|c|c|c|c|c|}
\hline $\begin{array}{l}\text { Factor } \\
\text { number }\end{array}$ & $\begin{array}{l}\text { Factor } \\
\text { loading }\end{array}$ & $\begin{array}{c}\text { Mean } \\
\text { responses }\end{array}$ & Eigenvalue & 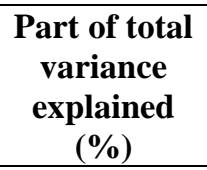 & $\begin{array}{c}\text { Part of total } \\
\text { variance explained } \\
\text { (cumulative\%) }\end{array}$ \\
\hline $\begin{array}{c}\text { Normative } \\
\text { commitment } 1\end{array}$ & 0.8541 & 2.08 & 5.072 & 27.2 & 56.7 \\
\hline $\begin{array}{c}\text { Normative } \\
\text { commitment } 2\end{array}$ & 0.6924 & 2.17 & & & \\
\hline $\begin{array}{c}\text { Normative } \\
\text { commitment } 3\end{array}$ & 0.7081 & 2.89 & & & \\
\hline $\begin{array}{c}\text { Normative } \\
\text { commitment } 4\end{array}$ & 0.8221 & 3.47 & & & \\
\hline $\begin{array}{l}\text { Normative } \\
\text { commitment } 5\end{array}$ & 0.6395 & 3.98 & & & \\
\hline $\begin{array}{c}\text { Normative } \\
\text { commitment } 6\end{array}$ & 0.7992 & 2.71 & & & \\
\hline $\begin{array}{l}\text { Continuance } \\
\text { commitment } 1\end{array}$ & 0.7114 & 4.17 & 3.622 & 22.5 & 79.2 \\
\hline $\begin{array}{l}\text { Continuance } \\
\text { commitment } 2\end{array}$ & 0.7985 & 4.18 & & & \\
\hline $\begin{array}{c}\text { Continuance } \\
\text { commitment } 3\end{array}$ & 0.8215 & 3.58 & & & \\
\hline $\begin{array}{l}\text { Continuance } \\
\text { commitment } 4\end{array}$ & 0.7129 & 4.29 & & & \\
\hline $\begin{array}{l}\text { Continuance } \\
\text { commitment } 5\end{array}$ & 0.6932 & 3.09 & & & \\
\hline $\begin{array}{l}\text { Continuance } \\
\text { commitment } 6\end{array}$ & 0.6824 & 3.17 & & & \\
\hline
\end{tabular}

The graph below represents the decrease in eigenvalues from the results of the first PCA, showing the associated deviation of the factor axes. Indeed, the projection of the 18 items after a normalized varimax rotation opposes three types of organizational commitment (figure 3). The sum of the variance explained by each of the three factorial axes represents part of the total variance and reflects the reliability of the reading of the projections. Moreover, the factor analysis conducted on the 18 items specific to organizational commitment shows that the first axis represents $29.5 \%$ of the total variance. For the second factorial axis, which accounts for $27.2 \%$ of the total variance, six items take up approximately the construction of normative commitment. Finally, the PCA conducted on the remaining six items shows that the third factorial axis represents continuance commitment and accounts for $22.5 \%$ of the total variance.

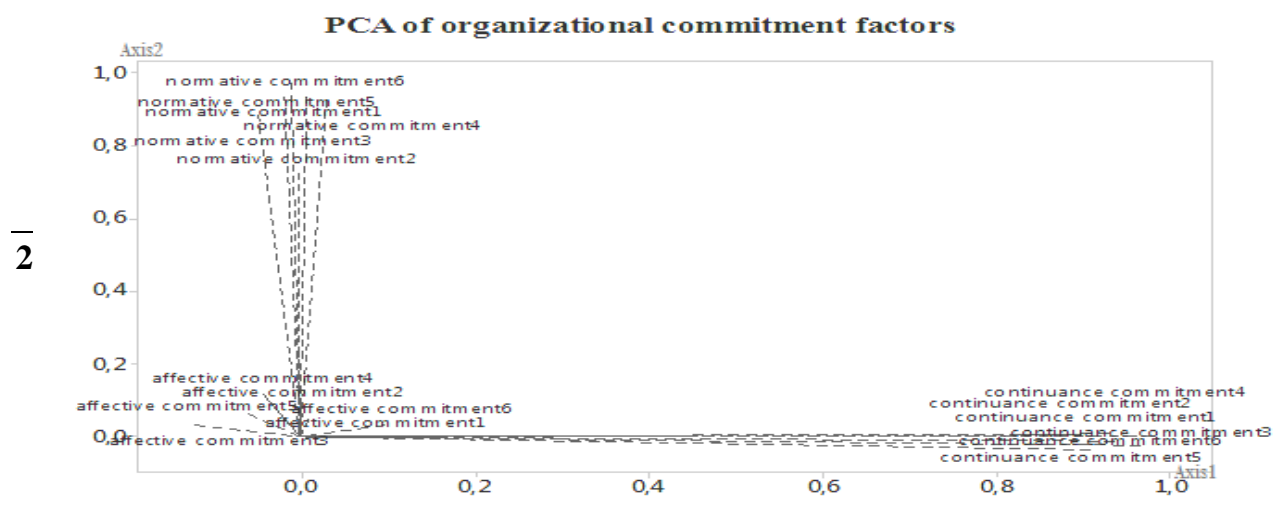


Figure 3. PCA of organizational commitment factor

\subsection{Empirical study of the relationship between intrinsic factors of satisfaction at work and organizational commitment}

To find the best estimation method for each of the model equations, we proceeded by identifying our equations. Indeed, the blind application of the ordinary least squares (OLS) method can result in erroneous results because the hypothesis of independence between the explanatory variable and the error is not respected. Thus, the parameters of the model's structural form can be assessed when the equations are exactly identified and over-identified. The methods with limited information that estimate the equation-by-equation model under the assumption that there is no correlation between the errors of the different equations can be distinguished from those with complete information that consider the model as a whole and estimate the parameters under the assumption that there are no cross-equation error correlations.

We constructed an econometric model with three equations explaining affective, normative, and continuance commitments, respectively. They are all independent equations (Greene, 2005); the "Seemingly Unrelated Regressions" (SUR) method aims to exploit the probable linkage of the errors of the different equations (Cadoret et al., 2004). The three types of these equations are estimated simultaneously to introduce the existing interactions between endogenous variables and the indirect effects of instrumental variables. The conceptual model is written as follows:

Affective commitment $=\alpha 0^{*}$ Achievement $+\alpha 1 *$ Advancement $+\alpha 2 *$ Work itself + $\alpha 3 *$ Recognition $+\alpha 4 *$ Growth $+\varepsilon 1$

Normative commitment $=\beta 0^{*}$ Affective commitment $+\beta 1 *$ Achievement + $\beta 2 *$ Advancement $+\beta 3 *$ Work itself $+\beta 4 *$ Recognition $+\beta{ }^{*}$ Growth $+\varepsilon 2$

Continuance commitment $=\gamma 0^{*}$ affective commitment $+\gamma I^{*}$ Normative commitment $+\gamma 2 *$ Achievement $+\gamma \quad 3 *$ Advancement $+\gamma 4^{*}$ Work itself $+\gamma$ $5 *$ Recognition $+\gamma 6 *$ Growth $+\varepsilon 3$ 
The elements $\varepsilon 1, \varepsilon 2$, and $\varepsilon 3$ refer to random disturbances.

We note that the three types of $\mathrm{OC}$ in one equation appear as explanatory variables in another, which leads to bias in the coefficients estimates when we use OLS, equation by equation.

The interactions between the three dimensions in the triangle "Affective-normativecontinuance" were treated in the econometric model while highlighting the role of the intrinsic determinants in each equation. Then, the results of affective commitment, normative commitment, and continuance commitment equations were interpreted to determine the model's condensed form.

\subsubsection{The Affective Commitment Equation}

We used Equation (1) to recognize the effects of the intrinsic determinants of satisfaction at work on affective commitment. Durbin and Watson's statistic suggests a self-correlation of errors. The findings show that $\mathrm{Fcal} \geq \mathrm{Ft}$; then, the hypothesis that the estimated parameters of the regression are not all zero is accepted. Thus, the model is overall significant.

Table 5 illustrates that only "Work itself" is not significant. All intrinsic variables have a positive and significant effect on affective commitment. This result is consistent with those of (Prat dit Hauret, 2006; Setiawan \& Ghozali, 2013). Indeed, professionals whose commitment is affective remain in the firm because they are attached through the intrinsic factors of satisfaction.

Therefore, the hypothesis that the intrinsic determinants of satisfaction at work affect affective commitment (H1.1.) is validated. The intrinsic factors of satisfaction, namely achievement, recognition, promotion, and growth, have a positive and significant effect on affective commitment, except for the work itself, which has a negative but insignificant effect. Indeed, the nature of the work performed by the accounting professionals seems exhausting and tiring: its structures, how decisions are made, the forms of cooperation are somewhat deplorable. This suggests that the work as it is performed does not have a positive and significant effect on affective commitment. 
The impact of intrinsic satisfaction factors on affective, normative, and continuance commitment of accounting professionals in Tunisia

Table 5. Results of the Affective Commitment Equation

\begin{tabular}{ccccc}
\hline Variables & Coefficient & Std.error & t-statistic & Prob \\
\hline Achievement & $0.34123^{*}$ & 0.17453 & 1.879 & 0.070 \\
Advancement /or promotion & $0.57411^{* * *}$ & 0.0412 & 3.36 & 0.0001 \\
Work itself & -0.10845 & 0.3214 & -1.04 & 0.44 \\
Recognition & $0.74412^{* *}$ & 0.27436 & 2.04 & 0.021 \\
Growth & $0.63841^{* * *}$ & 0.07454 & 4.04 & 0.000 \\
R2 adjusted & & 0.69 & & \\
F-statistic & & 35.31 & & \\
Prob (F-statistic) & & 0.0702 & & \\
Durbin-Watson stat & & 2.2009 & & \\
Log likelihood & & -58.4192 & \\
Sum of squared residuals & & 45.0087 & & \\
\hline Note: Number & & & \\
\hline
\end{tabular}

Note: Number of observations: 180 ;***Significant at 1\%; **Significant at 5\%;

*Significant at $10 \%$.

\subsubsection{The Normative Commitment Equation}

We used Equation (2) to identify the impact of the intrinsic determinants of satisfaction at work on normative commitment (Table 6). Durbin and Watson's statistic suggests a 'self-correlation of errors' that is validated in what follows. The results show that $\mathrm{Fcal} \geq \mathrm{Ft}$; So, the hypothesis that not all regression parameters are zero is accepted. Therefore, the model is overall significant. There is a significant correlation between the intrinsic determinants of satisfaction at work and normative commitment. This finding corroborates those of (Gunlu et al., 2010; Gangai \& Agrawal, 2015); professionals having normative commitment stay in their jobs due to the effect of professional and ethical standards. Accounting professionals in Tunisia behave faithfully towards the firm since they are satisfied. Hypothesis (H.1.2.) that stipulates that the intrinsic factors of satisfaction at work affect normative commitment is validated.

The intrinsic factors of satisfaction, namely achievement, work itself, promotion, and growth, have a positive and significant effect on normative commitment, except for recognition, which has a negative but insignificant effect. The feeling of gratitude is somewhat neglected: it does not have a positive effect on normative commitment and is not an essential element of the firm operation efficiency. Accounting professionals are much more concerned with their achievement at work (Respected, competitive, competent) than the recognition of their sense of prestige and esteem. 
Table 6. Results of the normative commitment equation

\begin{tabular}{|c|c|c|c|c|}
\hline Variables & Coefficient & Std.error & t-statistic & Prob \\
\hline Affective commitment & $-0.12546 *$ & 0.32145 & 1.75 & 0.082 \\
\hline Achievement & $0.621871 * * *$ & 0.098521 & 3.21 & 0.0000 \\
\hline Advancement /or promotion & $0.51214 * *$ & 0.0032 & 2.07 & 0.022 \\
\hline Work itself & $0.22814 *$ & 0.18732 & 1.69 & 0.098 \\
\hline Recognition & -0.017452 & 0.35201 & 1.66 & 0.198 \\
\hline Growth & $0.369884 * * *$ & 0.16325 & 4.44 & 0.000 \\
\hline $\mathrm{R} 2$ adjusted & & & & 0.56 \\
\hline F-statistic & & & & 44.32 \\
\hline Prob (F-statistic) & & & & 0.000 \\
\hline Durbin-Watson stat & & & & 1.9541 \\
\hline Log likelihood & & & & -69.32147 \\
\hline Sum of squared res & & & & \\
\hline
\end{tabular}

Note: Number of observations: $180 ; * * *$ Significant at $1 \% ; * *$ Significant at $5 \%$;

*Significant at $10 \%$

\section{The Continuance Commitment Equation}

We used Equation (3) to explain the effects of the intrinsic determinants of satisfaction at work on continuance commitment (Table 7). Durbin and Watson's statistic suggests that errors are self-correlated. The third Equation shows that $\mathrm{Fcal} \geq \mathrm{Ft}$; therefore, the hypothesis that the estimated regression parameters are not all zero is accepted. Consequently, the model is overall significant.

The intrinsic factors of satisfaction at work affect continuance commitment significantly. This finding confirms that of (Sreehari et al., 2014; Tosun \& Ulusoy, 2017); professionals having continuance commitment remain in their jobs because the cost of quitting in Tunisia is too high. The hypothesis that intrinsic factors of satisfaction at work affect continuance commitment (H1.3.) is confirmed.

The intrinsic factors of satisfaction, namely achievement, recognition, promotion, and growth, have a positive and significant effect on continuance commitment, except for achievement, which has a negative but insignificant effect. What accounting professionals seek in the workplace is rather esteem and recognition of their desire for promotion than the need for accomplishment through the exercise of responsibilities and power, which are based primarily on the relationships between the different stakeholders, whose conflicts of interest and asymmetry of information are the norm. However, we deduce that the accounting firm constitutes an environment that is conducive to the outbreak of conflicts, be it conflicts between 
The impact of intrinsic satisfaction factors on affective, normative, and continuance commitment of accounting professionals in Tunisia

young and old accounting professionals or between women and men accounting professionals.

Table 7. Results of the Continuance Commitment Equation

\begin{tabular}{lrrrr}
\hline \multicolumn{1}{c}{ Variables } & Coefficient & Std.error & t-statistic & \multicolumn{1}{c}{ Prob } \\
\hline Affective commitment & -0.04783 & 0.00789 & 0.98 & 0.744 \\
continuance commitment & $0.28451^{* *}$ & -0.0547 & 1.87 & 0.077 \\
Achievement & -0.03651 & 1.2145 & -1.59 & 0.122 \\
Advancement /or promotion & $0.6845^{* * *}$ & 2.0058 & 2.89 & 0.001 \\
Work itself & $0.45512^{* *}$ & 1.3621 & 1.88 & 0.044 \\
Recognition & 0.50012 & 1.3365 & 2.07 & 0.004 \\
Growth & $0.369884^{* * *}$ & 0.16325 & 4.44 & 0.000 \\
R2 adjusted & & & & 0.78 \\
F-statistic & & & & 56.77 \\
Prob (F-statistic) & & & & 0.000 \\
& & & & 2.08475 \\
Durbin-Watson stat & & & -77.36251 \\
Log likelihood & & & 29.1412 \\
Sum of squared residuals & & & & \\
\hline Note: Number of
\end{tabular}

Note: Number of observations: $180 ; * * *$ Significant at $1 \% ; * *$ Significant at 5\%;

*Significant at $10 \%$.

\section{Conclusion}

We aimed to study the effect of intrinsic satisfaction factors on the three dimensions of organizational commitment, namely affective, normative, and continuance, of accounting professionals in Tunisia. Following the literature review, we posed three main sub-hypotheses in the aim of our work. They deal with the impact of intrinsic factors on affective, normative, and continuance commitment, respectively.

Our findings prove that the intrinsic satisfaction factors, namely achievement, advancement, work itself, recognition, and growth, have a positive and significant effect on accounting professionals' affective, normative, and continuance commitment (Shafazawana et al., 2016). Throughout this work, we followed a research approach that satisfies the requirements of methodology and scientific rigor. Nevertheless, as any research work, this work has some limitations, such as the limited sample size, which makes it difficult to generalize the obtained results. Furthermore, the use of the questionnaire is another limitation, especially that its advantage of obtaining a larger number of participants was not fully achieved. Our findings highlight the need for new lines of research to extend our results and conclusions. For example, future work may deal with the effect of satisfaction and affective, normative, and continuance commitments of the audit team on the audit quality.

Vol. 20, No. 2 


\section{References}

Abdelmoula, L. \& Boudabbous, S. (2020) "The indirect impact of satisfaction on accounting professionals' performance: Tunisian context”, Accounting, vol. 6, no. 6: 1021-1032.

Abdelmoula, L. (2020) "The impact of extrinsic job satisfaction factors on the organizational commitment of accounting professionals in Tunisia", Management Science Letters, vol. 10, no. 3:3003-3008.

Allen, N.J. \& Meyer, J.P. (1990) "The measurement and antecedents of organizational commitment: re-examination of the affective and continuance commitment scales", Journal of Applied Psychology, vol. 72, no. 4:638-642.

Aranya, N., Lachman, R \& \&Amernic, J. (1982) "Accountants, job satisfaction: a path analysis", Accounting, Organizations and Society, vol. 7, no. 3: 201-215

Blau, P.M. (1964) "Exchange and power in social life", New York: Wiley. Management, vol.30:153-180.

Cadoret,I., Benjamin,C. \& Martin,F.(2004) "Econometrie appliquee”, lere ed., De Boeck, Bruxelles,

Dubar, C., Tripier, P. \& Boussard, V. (2011) “Sociologie des professions”, Paris, 3e édition, Armand Colin, coll. U, 376 p.

Evrard, Y., Pras, B. et Roux, E. (2009). " Market - Études et recherches en marketing”, 4ème édition. Paris: Dunod.

Gangai, K.N. \& Agrawal,R (2015) "Job Satisfaction and Organizational Commitment: Is It important for Employee Performance", International Journal of Management and Business Research, vol. 5, no. 4 : 269-278.

Gomeshu Goa, G. \& Fanta, A. (2018) "The Effects of Intrinsic Job Satisfaction on Employees' Organizational Commitment; The Study on Commercial Bank Of Ethiopia", WolaitaSodo District, International Journal of Business and Management Invention, vol. 7, no. $4: 36-47$.

Greene,H .(2005) "Econometric Analysis", 1st edition . MacMillan.

Gregson, T. (1992) "An Investigation of the causal ordering of job satisfaction and organizational commitment in turnover models in accounting", Behavior Research in Accounting, vol.4:80-95.

Gunlu, E., Aksarayli, M. \& Perçin, N. S. (2010) "Job satisfaction and organizational commitment of hotel managers in Turkey", International Journal of Contemporary Hospitality Management, vol. 22: 693-717.

Herzberg, F., Mausner, B. \&, Snyderman, B. (1959) "The Motivation to Work", Wiley, New York

Hong, T. \& Waheed, A. (2011) "Herzberg's motivation-hygiene theory and job satisfaction in the Malaysian retail sector: the mediating effect of love of money", Asian Academy of Management Journal, Vol. 16, no. $1: 73-94$

Law n ${ }^{\circ} 2002-16$ of 4 February 2002 for Accountants.

Law n ${ }^{\circ} 88-108$ of 18 August 1988 bearing an overhaul of the legislation relative to the profession of Chartered Accountants and Chartered Accountants Trainees. 
Luttman, S., Mittermaier, L. \& Rebele, J. (2003) "The association of career stage and gender With tax accountants' work attitudes and behaviours", Advances in Taxation, 15: 111-143.

Meyer, J. P. \& Allen, N. J. (1997) Commitment in the workplace: Theory, research, and application, Sage.

Meyer, J. P., Allen, N. J. \& Smith, C. A. (1993) "Commitment to Organizations and Occupations: Extension and Test of a Three-Component Conceptualization", Journal of Applied Psychology, vol. 78, no. 4 : 538-551.

Mowday, R., Steers, R., \& Porter, L. (1979) "The measurement of organizational commitment", Journal of Vocational Behavior, vol. 14: 224-247.

Prat dit Hauret, C. (2006) "Are organizational commitment and job satisfaction pertinent concepts for trainee accountants", Accounting Auditing Control, vol. 12 , no. 1 :125-146.

Rebele, J.E., Michaels, R.E. \& Wachter, J.W. (1996) "The relationship of career stage to job outcome and role stress: A study of external auditors", Advances in Accounting, vol. 14: 241-258.

SaportaG. (2006) "Probabilités, Analyse des Données et Statistique", Technip.

Sarfatti, L. (1977) "The Rise of Professionalism" Berkeley: University of California Press.

Sejjaaka, S.K. \& Kaawaase, T.K. (2014) "Professionalism, rewards, job satisfaction and organizational commitment amongst accounting professionals in Uganda", Journal of Accounting in Emerging Economies, vol. 4, no. 2: 134-157.

Setiawan, I.A. \& Ghozali, I. (2013) "Multidimensional causal path on organizational commitment and job satisfaction in intention to leave by accountants", Journal of Economics, Business, and Accountancy Ventura, vol. 16, no. 1: 339-354.

Shafazawana, M.T., Ying, C.Y., Zuliawati, M.S. \& Kavitha, S. (2016) "Managing job attitudes: the roles of job satisfaction and organizational commitment on organizational citizenship behaviors", Procedia Economics and Finance, vol. 35: $604-611$.

Smith, P.C., Kendall, L.M. \& Hulin C.L. (1969) The Measurement of Satisfaction in Work and Retirement: A Strategy for the Study of Attitudes, Rand McNally, Oxford.

Spector, P.E. (1985) "Measurement of human service staff satisfaction: Development of the job satisfaction survey", American Journal of Community Psychology, vol. 13, no. 6: 693-713.

Sreehari, R., Jomon., J. \& Joseph, T.R. (2014) "Exploring the relationship between job satisfaction and organizational commitment of nurses", International Journal of Accounting \& Business Management, vol. 2, no. 1 : 84-86.

Srivastava,S.(2013) "Job satisfaction and organizational commitment relationship: effect of personality variables", The Journal of Business Perspective, vol. 17, no. 2:159-167. 
Susanto, Y.K. (2012) "Organizational and professional commitment and their effect on job satisfaction, Journal of Economics, Business, and Accountancy Ventura, vol. 15, no. 1: 127-132.

Tat, H. H., Pei-Ni, T.\& Rasli, A. M. (2012) "Job satisfaction and organizational commitment in a Malaysian Public University's Library", International Journal of Management Sciences and Business Research, 1, 1-7.

Thabane, L.J., Radebe, P.Q. \& Dhurup, M. (2017) "The Effect of Job Satisfaction on the Organisational Commitment of Administrators", Journal of Economics and Behavioral Studies, vol. 9, no. $6: 188-198$.

Top, M. \& Gider, O. (2013). Interaction of organizational commitment and job satisfaction of nurses and medical secretaries in Turkey", The International Journal of Human Resource Management, vol.24, 667-683.

Tosun, N. \& Ulusoy, H. (2017) "The relationship of organizational commitment, job satisfaction and burnout on physicians and nurses", Journal of Economics and Management, vol. 28, no. $2: 90-111$.

Westland, J.C. (2010) "Lower bounds on sample size in structural equation modeling. Electronic Commerce", Research and Applications, vol. 9, no. 6: 476-487. 


\section{- Affective commitment}

\section{Appendix}

1. I really have a feeling of belonging to my firm.

2. My firm means a lot to me

3. I am proud to belong to this firm.

4. I feel emotionally attached to my firm

5. I really feel like "being part of the family" in my firm.

6. I consider the problems of my firm as mine.

\section{- Normative commitment}

7. It would not be morally correct to leave my firm now.

8. It would not be correct to leave my firm now even if I found an advantage.

9. I feel that I would be guilty if I left my organization now.

10. I would betray the trust that I am granted if I left my firm now.

11. If I were offered a position in another organization, I would not find it correct to leave my current firm.

12. I am not leaving my organization now because I feel that I have obligations towards some people who work there.

\section{- Continuance commitment}

13. I have no choice but to stay in my current firm.

14. I stay in my current firm because I do not see if I could go elsewhere.

15. I continue to work for my current firm because I feel that my opportunities to work elsewhere are too limited.

16. I continue to work for my current firm because I derive many benefits from it

17. I continue to work for my current firm because I see a lot more advantages than disadvantages.

18. I continue to work for this firm because another firm could not offer me the same benefits.

\section{- Intrinsic satisfaction factors}

\section{$>$ Achievement}

1. I am delighted to work in this firm as it acknowledges my achievements.

2. I feel fulfilled with my job because it gives me a feeling of accomplishment.

3. I feel I have participated in my firm positively.

\section{$>$ Advancement}

4. I will choose career development rather than financial incentives.

5. My job enables me to learn new skills for career development.

$>$ Work Itself

6. My work is stimulating, and I do diverse tasks.

7. I am qualified enough to do my job.

8. My job is challenging and exciting.

$>$ Recognition

9. I feel appreciated when I achieve or complete a task. 
10. My director always expresses recognition for a well-done job.

11. I receive adequate recognition for doing my job well.

$>$ Growth

12. I am proud to work in my firm because I feel I have grown as a person.

13. My job enables me to progress and develop as an individual.

14. My job enables me to improve my experience, skills and performance. 